\title{
Interchangeable effects of gibberellic acid and temperature on embryo growth, seed germination and epicotyl emergence in 1,2 Ribes multiflorum ssp. sandalioticum (Grossulariaceae)
}

\author{
E. Mattana ${ }^{1}$, H. W. Pritchard ${ }^{2}$, M. Porceddu ${ }^{1}$, W. H. Stuppy ${ }^{2}$ \& G. Bacchetta ${ }^{1}$ \\ 1 Centro Conservazione Biodiversità (CCB), Dipartimento di Scienze della Vita e dell'Ambiente, Università degli Studi di Cagliari, Italy \\ 2 Seed Conservation, Royal Botanic Gardens, Kew, Wakehurst Place, Ardingly, West Sussex, UK
}

\section{Keywords}

Cold stratification; morphophysiological dormancy; Sardinian endemic; secondary dormancy; warm stratification; water uptake.

\section{Correspondence}

E. Mattana, Centro Conservazione

Biodiversità (CCB), Dipartimento di Scienze della Vita e dell'Ambiente, Università degli

Studi di Cagliari, Viale Sant'Ignazio da

Laconi, 13, 09123, Italy.

E-mail: mattana.efisio@gmail.com

\section{Editor}

S. Wick

Received: 18 January 2011; Accepted: 31 March 2011

doi:10.1111/j.1438-8677.2011.00476.x

\begin{abstract}
Morphophysiological dormancy was investigated in seeds of Ribes multiflorum Kit ex Roem et Schult. ssp. sandalioticum Arrigoni, a rare mountain species endemic to Sardinia (Italy). There were no differences in imbibition rates between intact and scarified seeds, suggesting a lack of physical dormancy, while methylene blue solution $(0.5 \%)$ highlighted a preferential pathway for solution entrance through the raphe. Embryos were small at seed dispersal, with an initial embryo:seed ratio (E:S) of $c a .0 .2$ (embryo length, $c a .0 .5 \mathrm{~mm}$ ), whereas the critical E:S ratio for germination was three times longer (ca. 0.6). Gibberellic acid $\left(\mathrm{GA}_{3}, 250 \mathrm{mg} \cdot \mathrm{l}^{-1}\right)$ and warm stratification $\left(25^{\circ} \mathrm{C}\right.$ for 3 months) followed by low temperature $\left(<15{ }^{\circ} \mathrm{C}\right)$ enhanced embryo growth rate (maximum of $c a .0 .04 \mathrm{~mm} \cdot \mathrm{day}^{-1}$ at $10{ }^{\circ} \mathrm{C}$ ) and subsequent seed germination (radicle emergence; ca. $80 \%$ at $10{ }^{\circ} \mathrm{C}$ ). Low germination occurred at warmer temperatures, and cold stratification $\left(5^{\circ} \mathrm{C}\right.$ for 3 months) induced secondary dormancy. After radicle emergence, epicotyl emergence was delayed for ca. 2 months for seeds from three different populations. Mean time of epicotyl emergence was affected by $\mathrm{GA}_{3}$. Seeds of this species showed non-deep, simple (root)non-deep simple (epicotyl) morphophysiological dormancy, highlighting a high synchronisation with Mediterranean seasonality in all the investigated populations.
\end{abstract}

\section{INTRODUCTION}

Central northern Sardinia (Italy) has been identified as one of 52 putative refugia in the Mediterranean region (Médail \& Diadema 2009). Existence of these refugia implies the local long-term (one or more glacial-interglacial cycles) persistence of a species or population within a well-defined geographical area (e.g. mountain range, gorge). Central northern Sardinia also represents a southern European refugium (sensu Tzedakis et al. 2002) for some temperate tree species, such as Rhamnus alpina L., Taxus baccata L. and Sorbus torminalis (L.) Crantz, as detected in the Supramontes (a karstic region in central northern Sardinia) by Fenu et al. (2010). This area is also characterised by endemic species of genera typical of temperate climates, such as Ribes sardoum Martelli and Ribes multiflorum Kit ex Roem et Schult. ssp. sandalioticum Arrigoni, which are exclusive to the island and are the only two members of the genus in Sardinia.

Ribes L. (Grossulariaceae) is a genus of $c a .200$ species distributed in temperate regions of the Northern Hemisphere and the Andes, with many species being cultivated for their edible fruits or ornamental purposes (Mabberley 2008). $R$. sardoum, the Sardinian currant, is a very rare and threatened species with only one small population in the Supramontes (Monte Corrasi, $1200 \mathrm{~m}$ a.s.l.). R. multiflorum ssp. sandalioticum is found in small populations in the Supramontes, Gennargentu Massif, Catena del Marghine and Limbara Mountain, growing at altitudes above $1000 \mathrm{~m}$ a.s.l., under the canopy of temperate woodlands, among mountainous streams and on wet slopes (Arrigoni 1968, 1981; Valsecchi 1977).

The seeds of Grossulariaceae are anatropous and characterised by a single layer, gelatinous sarcotesta, arillate to exarillate and albuminous. The sarcotesta is constituted of thin-walled palisade-like cells of the outer testa epidermis whose lumina are filled with mucilage. The inner epidermis of the outer integument (endotesta) consists of a layer of small cuboid crystal cells, with thickened and lignified radial and inner walls and one to three crystals per cell (Corner 1976). Of the two-layered inner integument (tegmen), the outer epidermis is crushed during seed development, whereas the inner epidermis (endotegmen) persists as a layer of enlarged thin-walled cells with firm, brown tanniniferous content. The vascular system of the seed is constituted only of a raphe bundle. The endosperm is oily, with slightly thickened walls, and the embryo is small relative to the endosperm (Corner 1976). Embryos of mature seeds of Ribes spp. are classified as linear underdeveloped (Martin 1946; Baskin \& Baskin 2007), with a mean embryo:seed (E:S) ratio of about 0.04 (Forbis et al. 2002). The seeds of most Ribes spp. have 
embryo dormancy, which can be broken by a long, cold stratification period (Young \& Young 1992). This period can range from 60 to 300 days, depending on species, and consists of prechilling, warm stratification followed by prechilling, and/or a wide range of diurnal temperature to facilitate germination (Ellis et al. 1985; Baskin \& Baskin 1998). A lower temperature can improve germination and reduce the prechilling requirement (Fivaz 1931; Pfister 1974). High germination percentages (about 100\%) have been achieved for several Ribes spp. without any pre-treatment (Liu et al. 2008). However, seed coat dormancy, controlled by growth inhibitors and/or an impermeable seed coat, is also suspected to occur (Pfister 1974; Goodwin \& Hummer 1993; Rosner et al. 2003a,b). In particular, sulphuric acid and hydrogen peroxide treatments improve germination in some species (Fivaz 1931; Adam \& Wilson 1967; Pfister 1974; Rosner et al. 2003a,b). Nonetheless, Baskin et al. (2000) did not consider the Grossulariaceae among families of angiosperm with seeds showing physical dormancy (PD).

Morphophysiological dormancy (MPD) has been inferred to occur in seeds of Grossulariaceae and particularly those of Ribes (Baskin \& Baskin 1998), but no studies have been done to substantiate this claim. In addition, if seeds of Ribes have MPD, then research will be required to determine which of the nine levels (non-deep simple, intermediate simple, deep simple, deep simple epicotyl, non-deep simple epicotyl, deep simple double, non-deep complex, intermediate complex and deep complex; Baskin \& Baskin 1998, 2004; Baskin et al. 2008) is present.

To help determine the class of dormancy, information is needed on seed coat permeability to water, responses to warm and/or cold stratification and to plant hormones, in particular gibberellic acid (GA). To resolve the nature of dormancy, especially MPD, 'move-along experiments' (or double germination phenology technique) have been used to determine the temperature, or temperature sequence, required to break dormancy and promote germination. This approach mimics the environment into which dormant seeds are dispersed and subsequently exposed, and is applicable to both temperate and tropical environments (e.g. Baskin \& Baskin 2003; Hoyle et al. 2008).

The balance between abscisic acid (ABA) and GA and sensitivity to these hormones regulates the onset, maintenance and termination of dormancy. ABA synthesis and signalling (GA catabolism) dominate the dormant state, whereas GA synthesis and signalling (ABA catabolism) dominate the transition to germination (Finch-Savage \& Leubner-Metzger 2006). For this reason, Baskin \& Baskin (2004) considered the ability of exogenous GA to overcome dormancy a decisive element in distinguishing among levels of PD in their dormancy classification systems.

Dormancy breaking and germination requirements are specific for each species and depend on phylogeny, distribution and habitat (Baskin \& Baskin 1998, 2004; Finch-Savage \& Leubner-Metzger 2006). Even closely related species, either growing in a variety of habitats (e.g. Vandelook et al. 2008) or co-occurring in a given habitat, may differ in germination response to environmental signals (e.g. Daws et al. 2002; Karlsson et al. 2008). Intra-specific variation in the depth of dormancy or germination requirements among populations/ecotypes has been related to differences in postdispersal environment (Donohue 2005), mainly due to altitude or habitat (e.g. Milberg \& Andersson 1998; GiménezBenavides et al. 2005; Mondoni et al. 2008).

The main aim of this study was to investigate the seed germination ecology of $R$. multiflorum ssp. sandalioticum in order to: (i) identify the class of dormancy, sensu Baskin \& Baskin (2004), and if MPD is present, at what level, and (ii) confirm whether seedlots from different populations vary in their response to treatments.

\section{MATERIALS AND METHODS}

\section{Seedlot details}

Ripe fruits of $R$. multiflorum ssp. sandalioticum (hereafter, $R$. m. sandalioticum) were collected directly from plants in three populations, representative of its distribution, at the time of natural dispersal in 2008 and 2009 (Table 1). Seeds were immediately separated from the pulp by rubbing fruits through sieves under running water. The cleaned seeds were then spread out and left to dry at room temperature. Subsequently, seeds were placed in a dry room at $15 \% \mathrm{RH}$ and $15{ }^{\circ} \mathrm{C}$. Seedlot OR08 was then stored at $+5{ }^{\circ} \mathrm{C}$, until experiments with all seedlots commenced in 2009. Average seed mass was calculated for each seed lot by weighing 10 replicates of 20 seeds each (Table 1).

Climatic data for the three population site locations were acquired using the 'extract values to points' tool in GIS software (ESRI ArcMap version 9.2) from available data at a spatial resolution of $1 \mathrm{~km}^{2}$, downloaded from the WorldClim website (http://www.worldclim.org), as documented by $\mathbf{3}$ Hijmans et al. (2005).

\section{Imbibition}

The rate of water uptake was monitored for scarified and nonscarified seed in three replicates of 20 seeds each from seedlot OR08 (see Table 1). Seeds were longitudinally scarified

Table 1. Seed lot details.

\begin{tabular}{|c|c|c|c|c|c|}
\hline population & code & collection date & $\begin{array}{l}\text { substrate } \\
\text { (Carmignani et al. 2001) }\end{array}$ & altitude ( $m$ a.s.I.) & seed fresh weight (mg) \\
\hline M.te Novo San Giovanni, & OR08 & $23 / 08 / 2008$ & Mesozoic limestone & 1225 & $7.57 \pm 0.90$ \\
\hline $\begin{array}{l}\text { N.ghe Ortachis, } \\
\text { Bolotana (NU) }\end{array}$ & BO09 & 08/08/2009 & Cenozoic basalt & 1025 & $7.52 \pm 0.76$ \\
\hline $\begin{array}{l}\text { M.te Limbara, } \\
\text { Tempio (OT) }\end{array}$ & TE09 & $17 / 08 / 2009$ & Palaeozoic granite & 1300 & $5.01 \pm 0.17$ \\
\hline
\end{tabular}


through the testa and the tegmen, using a scalpel, and change in mass was monitored during incubation on the surface of $1 \%$ agar water in $60-\mathrm{mm}$ diameter plastic Petri dishes at $20{ }^{\circ} \mathrm{C}$ in the light ( $12 \mathrm{~h}$ light/12 h dark). Seeds were weighed at 1-, 2-, 4-, 6- and 20-h intervals and then every $24 \mathrm{~h}$ for the next 6 days (168 h in total). Percentage water uptake was calculated following Hidayati et al. (2001) in relation to seed mass at $t_{\mathrm{o}}$ : $\% \mathrm{~W}_{\mathrm{s}}=\left[\left(\mathrm{W}_{\mathrm{i}}-\mathrm{W}_{\mathrm{d}}\right) / \mathrm{W}_{\mathrm{d}}\right] \times 100$, where $\mathrm{W}_{\mathrm{s}}=$ increase in mass of seed, $\mathrm{W}_{\mathrm{i}}=$ mass of seed after a given interval of imbibition, and $\mathrm{W}_{\mathrm{d}}=$ seed mass at $\mathrm{t}_{\mathrm{o}}$.

An increase in seed mass could be caused through uptake of water by the sarcotestal gelatinous pulp, and not through imbibition of water by the embryo. Therefore, seeds were imbibed in a watery methylene blue solution $(0.5 \%)$ to clarify whether sufficient water penetrates the endosperm to reach the embryo (Tillman-Sutela \& Kauppi 1998). After 2, 15 and 30 days of imbibition in methylene blue, longitudinal and cross-sections were then made on seeds, both manually with a scalpel and

4 sectioned at $-20{ }^{\circ} \mathrm{C}$ using a cryotome (Leica CM3050S) and checked for staining under a Stemi SV 11 microscope (Carl Zeiss, Welwyn Garden City, Herts, UK), equipped with a digital microscopy camera (AxioCam HRc; Carl Zeiss MicroImag-

5 ing, Germany). Measurements were carried out using the image analysis software Axiovision 3.1.2.1 (Carl Zeiss Vision).

\section{Germination tests}

In an attempt to break seed dormancy, a 'move-along experiment' (Baskin \& Baskin 2003) was carried out (Table 2), starting in May 2009, on seedlot OR08 (see Table 1). Three replicates of 20 seeds each were sown on the surface of $1 \%$ agar water in $60-\mathrm{mm}$ diameter plastic Petri dishes and incu-

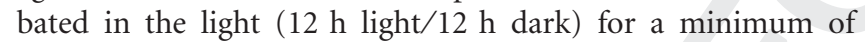
4 months and a maximum of 6 months at a range of germination temperatures $\left(10,15,20,25,30\right.$ and $\left.25 / 10^{\circ} \mathrm{C}\right)$, and further replicates were given different pre-treatments (Table 2). In the alternating temperature regime, the 12-h light period coincided with the elevated temperature period. The low number of seeds per replicate (20) in each experiment was due to limited seed availability because the species is rare and has small populations. Three extra replicates of 20 seeds each were sown on the surface of $1 \%$ agar water with
$250 \mathrm{mg} \cdot \mathrm{l}^{-1} \mathrm{GA}_{3}$ and incubated in the light $(12 \mathrm{~h}$ light/12 $\mathrm{h}$ dark, at the above germination temperatures.

Three extra replicates were incubated at $10{ }^{\circ} \mathrm{C}$ after chipping with a scalpel, and to confirm the effect of light on germination, another three replicates were also sown at $10^{\circ} \mathrm{C}$ in darkness (Petri dishes wrapped in aluminium foil).

Germination was defined as visible radicle emergence. Germinated seeds were scored three times at week, except for dark-incubated seeds that were only scored once, at the end of the test, to avoid any exposure to light. At the end of the germination tests, when no additional germination had occurred for 2 weeks, a cut-test was carried out to determine viability of remaining seeds and number of empty seeds. The final germination percentage was calculated on the basis of the total number of filled seeds and $\mathrm{T}_{50}$ values expressed as time to reach $50 \%$ maximum germination in one replicate.

\section{Embryo measurements}

Embryo growth during pre-treatments and germination conditions described above was assessed at different times (Table 2) by measuring five seeds for each sample interval. Seeds were cut in half under a dissecting microscope and images of embryos acquired using a flatbed scanner (Epson GT-15000) with a resolution of 1200 dpi. Embryo and seed 7 lengths were measured using the image analysis software ImageJ 1.41 (National Institutes of Health, USA) and the E:S 8 ratio calculated. Seed length was measured ignoring the seed coat. The initial E:S ratio was calculated by measuring 20 randomly selected seeds before the start of the experiments. The E:S ratio of seeds with a split seed coat but no radicle protrusion (critical E:S ratio) was determined for 20 randomly selected seeds and used for seeds that had germinated before measurements commenced (Vandelook et al. 2007). The mean rate of embryo growth was expressed in $\mathrm{mm}$ per day and calculated on the basis of number of days necessary to achieve the maximum E:S ratio.

\section{Population variability}

To evaluate differences in seed germination and epicotyl emergence (as a delay in epicotyl emergence had been detected in a

Table 2. Experimental design.

\begin{tabular}{|c|c|c|c|}
\hline \multicolumn{2}{|c|}{ pre-treatment } & \multicolumn{2}{|c|}{ embryo growth measurements } \\
\hline 0 & - & 4 & After $15,30,90$ and 120 days. \\
\hline C & 3 months, $5^{\circ} \mathrm{C}$ & 6 & $\begin{array}{l}\text { After } 45 \text { and } 90 \text { days during cold stratification (C), and } \\
15,30,90 \text { and } 120 \text { days after sowing for germination. }\end{array}$ \\
\hline$W+C$ & 3 months, $25^{\circ} \mathrm{C}(\mathrm{W}) \rightarrow 3$ months, $5^{\circ} \mathrm{C}(\mathrm{C})$ & 9 & $\begin{array}{l}\text { After } 45 \text { and } 90 \text { days during warm (W), 15, } 45 \text { and } 90 \text { days } \\
\text { during cold (C), and 15,30,90 and } 120 \text { days after sowing } \\
\text { for germination. }\end{array}$ \\
\hline$C+W+C$ & $\begin{array}{l}3 \text { months, } 5^{\circ} \mathrm{C}(\mathrm{C}) \rightarrow 3 \text { months, } 25^{\circ} \mathrm{C}(\mathrm{W}) \rightarrow 3 \text { months, } \\
5^{\circ} \mathrm{C}(\mathrm{C})\end{array}$ & 12 & $\begin{array}{l}\text { After } 45 \text { and } 90 \text { days during cold }(C), 15,45 \text { and } 90 \text { days } \\
\text { during warm (W), 15, } 45 \text { and } 90 \text { days during cold (C) and } \\
\text { 15, 30, } 90 \text { and } 120 \text { days after sowing for germination. }\end{array}$ \\
\hline
\end{tabular}


previous experiment) among populations, a warm pre-treatment, i.e. 3 months at $25{ }^{\circ} \mathrm{C}$ on the surface of $1 \%$ agar water (W, see Table 2), was applied in September 2009 to four replicates of 35, 25 and 20 seeds each from seedlots OR09, TE09 and $\mathrm{BO} 09$, respectively (Table 1 ), before transferring them to 5 and $10{ }^{\circ} \mathrm{C}$. The different number of seeds tested for each seedlot reflected seed availability. Germinated seeds were then: (i) kept at 5 and $10{ }^{\circ} \mathrm{C}$ for an additional 2-week period in order to allow root growth, before transplanting to a sterilised mixture (2:1) of sand/soil at 10,15 and $20^{\circ} \mathrm{C}$; (ii) kept (for seeds already incubated at $5{ }^{\circ} \mathrm{C}$ ) or moved (for seeds incubated at $10^{\circ} \mathrm{C}$ ) to $5^{\circ} \mathrm{C}$ for 2 months, before transplanting to (2:1) sand/soil at 10,15 and $20^{\circ} \mathrm{C}$; and (iii) kept at 5 and $10{ }^{\circ} \mathrm{C}$ for an additional 2 months on the surface of $1 \%$ agar water with $\mathrm{GA}_{3}\left(250 \mathrm{mg} \cdot \mathrm{l}^{-1}\right)$, before transplanting to $(2: 1)$ sand/soil at 10,15 and $20{ }^{\circ} \mathrm{C}$. The seeds and seedlings were scored daily and twice per week for radicle and epicotyl emergence, respectively. The mean time to emergence (MTE) was estimated according to the formula: $\mathrm{MTE}=\Sigma(\mathrm{ni} \times \mathrm{di}) / \mathrm{N}$, where ni is the number of emerged seedlings at day $i, d$ the incubation period in days, and $\mathrm{N}$ the total number of emerged seedlings in the treatment. When no additional germination or epicotyl emergence occurred for 2 weeks, after a minimum of 4 months, both germination and epicotyl emergence experiments were stopped.

\section{Statistical analysis}

One-way analysis of variance (ANOVA) was carried out on water uptake and rate of imbibition. Final germination (radicle emergence) and epicotyl emergence percentages and MTE values were analysed with one-way and two-way ANova; subsequently, a post hoc Fisher least significant difference test (LSD) was conducted. The non-parametric Kruskal-Wallis and Wilcoxon tests were used to test for differences in E:S ratios, seed and embryo lengths, rate of embryo growth and $\mathrm{T}_{50}$ values. All statistical analyses used R v. 2.11.1 (R Development Core Team 2010).

\section{RESULTS}

Imbibition

Both intact and scarified seeds reached maximum increase in mass $20 \mathrm{~h}$ after soaking, with a percentage water uptake of
$117.5 \pm 6.4 \%$ (mean \pm SD) and $111.8 \pm 1.2 \%$, at a rate of $0.416 \pm 0.032 \mathrm{mg} \cdot \mathrm{h}^{-1}$ and $0.394 \pm 0.003 \mathrm{mg} \cdot \mathrm{h}^{-1}$, respectively; these differences were not statistically significant at $\mathrm{P}>0.05$.

Methylene blue did not reach the endosperm or embryo, even though embryos had undergone significant imbibition (data not shown). After 2 days, the dye had partially stained the gelatinous sarcotesta (Fig. 1A), and after 15 days the endotesta was also completely stained blue (Fig. 1B). After 30 days, the endosperm and embryo were still unstained (Fig. 1C-F), suggesting that penetration of methylene blue through the seed coat was prevented by the outer epidermis of the tegmen (Fig. 1B-E). The dye stained the epistase in the micropylar region (Fig. 1D), the vascular bundle in the raphe (Fig. 1E) and its point of termination in the chalaza. The differential staining of tissues also highlighted the presence of a chalazal plug (hypostase) consisting of a tissue of brown (tanniniferous) cells that remained unstained (Fig. 1F).

\section{Embryo growth and root emergence}

Germination of R. m. sandalioticum seeds in light (74 $\pm 2 \%$ ) and darkness $(82 \pm 10 \%)$ at $10{ }^{\circ} \mathrm{C}$ was not significantly different $(\mathrm{P}>0.05)$. Also, no differences $(\mathrm{P}>0.05)$ were detected between germination of scarified and intact seeds (78 $\pm 3 \%$ and $74 \pm 2 \%$, respectively), with germination starting at about 20 days in both treatments.

The mean initial E:S ratio for $R$. $m$. sandalioticum seeds was $0.19 \pm 0.02$, with a mean embryo length of $0.52 \pm 0.08 \mathrm{~mm}$ and mean seed length of $2.70 \pm 0.23 \mathrm{~mm}$. The critical E:S ratio for germination was $0.62 \pm 0.12$, with a mean embryo length of $1.80 \pm 0.39 \mathrm{~mm}$ and mean seed length of $2.91 \pm 0.34 \mathrm{~mm}$. While mean seed length increased slightly (even if significantly: $\mathrm{P}<0.05$ ), mean embryo length increased more than three-fold $(\mathrm{P}<0.0001)$, consequently determining a highly significant increase in the mean E:S ratio $(\mathrm{P}<0.0001)$.

At the end of the first cycle of pre-treatments, after 90 days (I in Fig. 2), the mean E:S ratio was $<0.3$ for all seeds regardless of treatment temperature, and values were not statistically different from each other $(\mathrm{P}>0.05)$. While no germination occurred during warm stratification, $13 \pm 11 \%$ and $6 \pm 5 \%$ of seeds germinated at $5{ }^{\circ} \mathrm{C}$ in the two treatments started at this temperature $(\mathrm{C}$ and $\mathrm{C}+\mathrm{W}+\mathrm{C}$, respectively; Fig. 2).
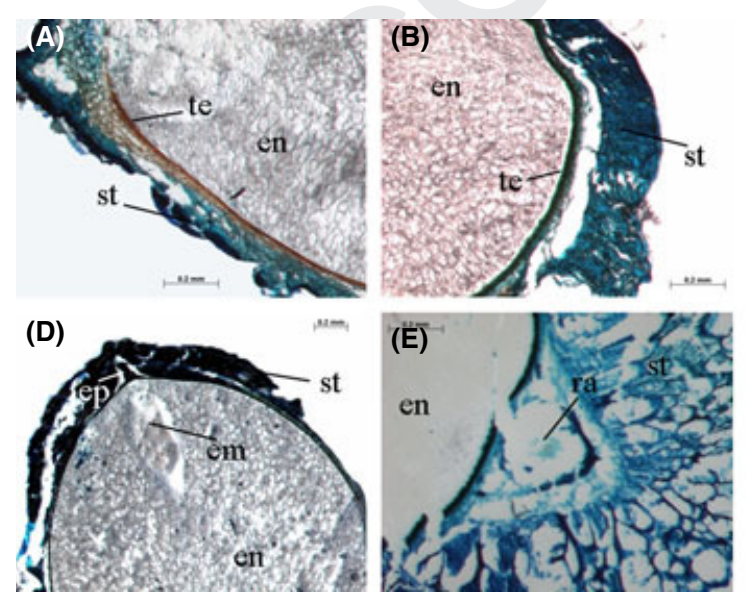

(C)
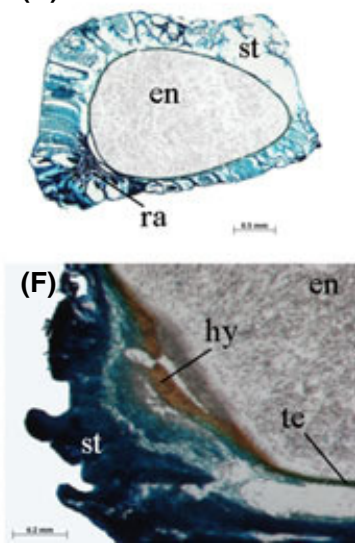

Fig. 1. Longitudinal (LS) and cross-sections (CS) of R. m. sandalioticum seeds (12- $\mu$ m thick) taken after soaking in methylene blue dye for different periods. LS after 2 (A) and 15 days (B); middle CS of seed (C), hilum region and epistase in LS after 30 days (D); detail of raphe in CS (E) and chalazal area in LS (F) after 30 days. Reference bars are $0.2 \mathrm{~mm}$, except for (C): $0.5 \mathrm{~mm}$. st: sarcotesta, te: tegmen, en: endosperm, em: embryo, ep: epistase, ra: raphe, hy: hypostase. 
During the second cycle of pre-treatments (II in Fig. 2), seeds receiving $\mathrm{W}+\mathrm{C}$ (90 day warm +90 day cold stratification) reached a critical E:S ratio after 135 days (45 days after the end of warm stratification; Fig. 2), whereas seeds receiving $\mathrm{C}+\mathrm{W}+\mathrm{C}$ (90 day cold +90 day warm +90 day cold stratification), the mean E:S ratio was still $<0.3(0.23 \pm 0.03)$ after 180 days at the end of warm stratification (Fig. 2). In seeds receiving $\mathrm{W}+\mathrm{C}$ germination was $71 \pm 14 \%$ after 180 days, while no more seeds incubated at $5{ }^{\circ} \mathrm{C}$ for 3 months and then at $25^{\circ} \mathrm{C}$ for 3 months $(\mathrm{C}+\mathrm{W}+\mathrm{C})$ had germinated at this time (Fig. 2).

The last cycle (III in Fig. 2) consisted of a further cold stratification $(\mathrm{C}+\mathrm{W}+\mathrm{C})$ and, at this point, after 270 days, embryos had a mean E:S ratio of $0.54 \pm 0.18$, which was not statistically different to the critical E:S ratio (0.62), and $35 \pm 1 \%$ of seeds germinated (Fig. 2). In summary, while no seeds germinated during warm stratification (W), 13\%, 71\% and $35 \%$ of seeds germinated at the end of $\mathrm{C}, \mathrm{W}+\mathrm{C}$ and $\mathrm{C}+\mathrm{W}+\mathrm{C}$, respectively (Fig. 2), with these percentages being statistically different $(\mathrm{P}<0.0001 ;$ Fig. $3 \mathrm{C})$. After pre-treatments, seeds were moved to germination conditions except for seeds that had received $\mathrm{W}+\mathrm{C}$ treatment, due to the high germination at the end of stratifications and scarcity of nongerminated seeds available for the experiments (see Fig. 2).

At $10{ }^{\circ} \mathrm{C}$, embryos of untreated seeds $(0)$ and those in the $\mathrm{W}$ treatment grew with at a mean rate of $0.042 \pm 0.002$ and $0.043 \pm 0.00 \mathrm{~mm} \cdot \mathrm{day}^{-1}$, respectively (Fig. 3A). Growth was

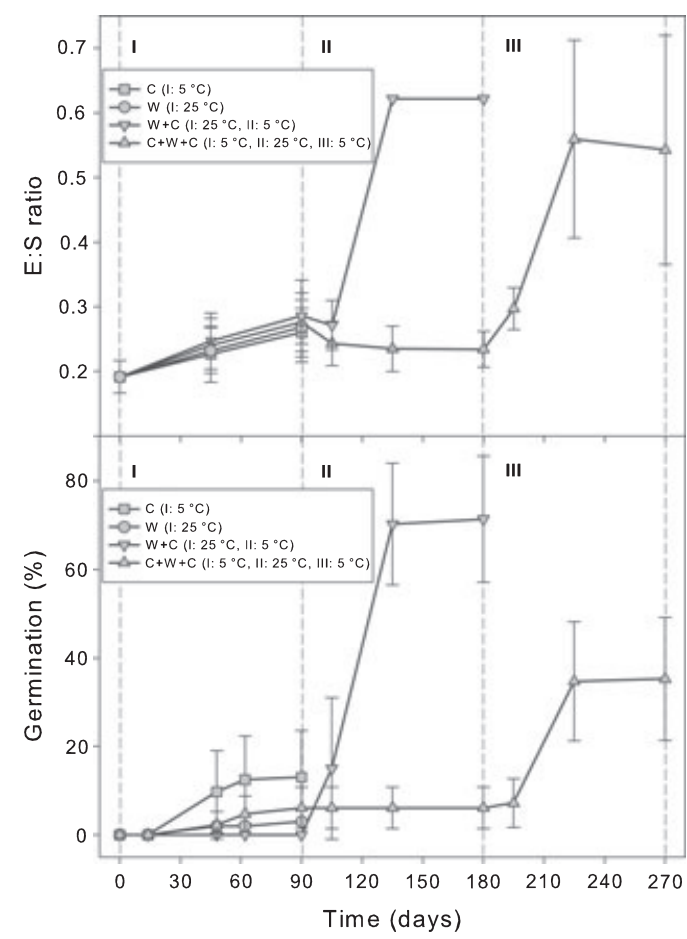

Fig. 2. Embryo:seed (E:S) ratio and germination during pre-treatments. I, II and III correspond to the three applied cycles of temperature, with $\mathrm{I}=5{ }^{\circ} \mathrm{C}$ for $\mathrm{C}$ and $25^{\circ} \mathrm{C}$ for 'pre-treatments for 3 months, $\|=5{ }^{\circ} \mathrm{C}$ for $\mathrm{W}+\mathrm{C}$ and $25^{\circ} \mathrm{C}$ for $\mathrm{C}+\mathrm{W}+\mathrm{C}$ pre-treatments for another 3 months, and $I I I=5{ }^{\circ} \mathrm{C}$ for $\mathrm{C}+\mathrm{W}+\mathrm{C}$ pre-treatment for the final 3 months. Data are mean of five seeds $( \pm S D)$ for $E$ :S ratio values and 18 replicates $( \pm S D)$ for germination data. ca. $0.010 \mathrm{~mm} \cdot \mathrm{day}^{-1}$ at $15{ }^{\circ} \mathrm{C}$ and always $\leq 0.05 \mathrm{~mm} \cdot \mathrm{day}^{-1}$ at warmer temperatures for both treatments (Fig. 3A). These differences were statistically significant within each pre-treatment $(\mathrm{P}<0.0001)$. After $\mathrm{C}$ and $\mathrm{C}+\mathrm{W}+\mathrm{C}$ treatments, embryos grew very slowly $\left(\leq 0.03 \mathrm{~mm} \cdot \mathrm{day}^{-1}\right)$ under all germination conditions, without statistical differences among temperatures $\left(\mathrm{P}>0.05\right.$; Fig. 3A). Seeds sown on $\mathrm{GA}_{3}$ solution showed the same trend to untreated (0) and warm stratified (W) seeds, with faster growth at cold temperatures, a mean rate of $0.043 \pm 0.00,0.011 \pm 0.00$ and $0.010 \pm 0.001 \mathrm{~mm} \cdot$ day $^{-1}$ at 10,15 and $25 / 10(17.5){ }^{\circ} \mathrm{C}$, respectively and lower mean rates at warmer temperatures, although above $0.006 \mathrm{~mm}$. day $^{-1}$ (Fig. 3A).

At the last measurement (after 120 days from sowing or from moving after pre-treatments; see Table 2), seeds reached a critical E:S ratio for germination at 10 and $15{ }^{\circ} \mathrm{C}$ for the 0 and $\mathrm{W}$ pre-treatment, while at warmer temperatures the mean E:S ratios were $0.4-0.5$ at $25 / 10(17.5)$ and $20^{\circ} \mathrm{C}$ and $<0.3$ at 25 and $30{ }^{\circ} \mathrm{C}$ (Fig. 2); these differences were statisti- 9 cally significant $(\mathrm{P}<0.001)$. After $\mathrm{C}$ and $\mathrm{C}+\mathrm{W}+\mathrm{C}$ pre-treatments, E:S ratios were low $(<0.5)$ at all tested temperatures, with no difference between conditions ( $\mathrm{P}>0.05$; Fig. $3 \mathrm{~B})$. In addition, mean E:S ratios detected at each germination temperature for $\mathrm{C}+\mathrm{W}+\mathrm{C}$ were lower than $\mathrm{E}: \mathrm{S}$ ratios detected at the end of stratifications (Figs 2 and 3B). Seeds treated with $\mathrm{GA}_{3}$ reached a critical E:S ratio at 10 and $15^{\circ} \mathrm{C}$ and high values (ca. 0.6) at $25 / 10(17.5)$ and $20^{\circ} \mathrm{C}$; these values were statistically significant $(\mathrm{P}<0.001$; Fig. $3 \mathrm{~B})$.

Germination followed the same trend as detected for embryo growth, with high germination at $10{ }^{\circ} \mathrm{C}$ of $74 \pm 2 \%$, $87 \pm 13 \%$ and $88 \pm 3 \%$ for $0, \mathrm{~W}$ and $\mathrm{GA}_{3}$, respectively, and $61 \pm 22 \%$ for C treatment (Fig. 3C), with no difference detected among treatments $(\mathrm{P}>0.05)$. Seeds also germinated at $15{ }^{\circ} \mathrm{C}$ in $0, \mathrm{~W}$ and $\mathrm{GA}_{3}$ treatments $(40 \pm 5 \%, 33 \pm 8 \%$ and $76 \pm 10 \%$, respectively, and not statistically different to germination at $10{ }^{\circ} \mathrm{C}(\mathrm{P}>0.05)$. Low germination $(<6.0 \%)$ was also detected at $25 / 10{ }^{\circ} \mathrm{C}$ (17.5) for $\mathrm{W}$ and $\mathrm{GA}_{3}$ and $20{ }^{\circ} \mathrm{C}$ for $\mathrm{GA}_{3}$ treatments. No germination occurred after $\mathrm{C}+\mathrm{W}+\mathrm{C}$ treatment (Fig. $3 \mathrm{C}$ ).

Although there were no statistical differences in the final germination percentages achieved at $10{ }^{\circ} \mathrm{C}$ after different pretreatments (Fig. 3C), the seeds germinated at different rates. Untreated seeds (0) needed $42 \pm 6$ day to reach $50 \%$ of maximum germination $\left(\mathrm{T}_{50}\right)$. After $\mathrm{W}$ and $\mathrm{GA}_{3}$ treatment, this time was approximately halved to $21 \pm 3$ and $27 \pm 1$ day, respectively. After $\mathrm{C}$ treatment, seeds germinated very slowly, with a $\mathrm{T}_{50}$ of $158 \pm 13$ day, nearly four-fold longer than the control $(0)$. The $\mathrm{T}_{50}$ values were statistically different $(\mathrm{P}<0.05$; Fig. 4).

\section{Population variability}

After W pre-treatment, seeds of Bolotana (BO09) and Orgosolo (OR09) populations had high germination percentages at $10{ }^{\circ} \mathrm{C}(94 \pm 2 \%$ and $96 \pm 2 \%$, respectively), while at the same temperature, germination of seeds from Tempio (TE09) was $41 \pm 14 \%$ (Fig. 5). Low germination (<30\%) was achieved in all seedlots after moving from $25{ }^{\circ} \mathrm{C}(\mathrm{W})$ to $5{ }^{\circ} \mathrm{C}$ (Fig. 5), with final values of $25 \pm 5 \%, 18 \pm 7 \%$ and $3 \pm 4 \%$ for Bolotana, Orgosolo and Tempio populations, respectively. The two-way ANOva highlighted that population and temper- 


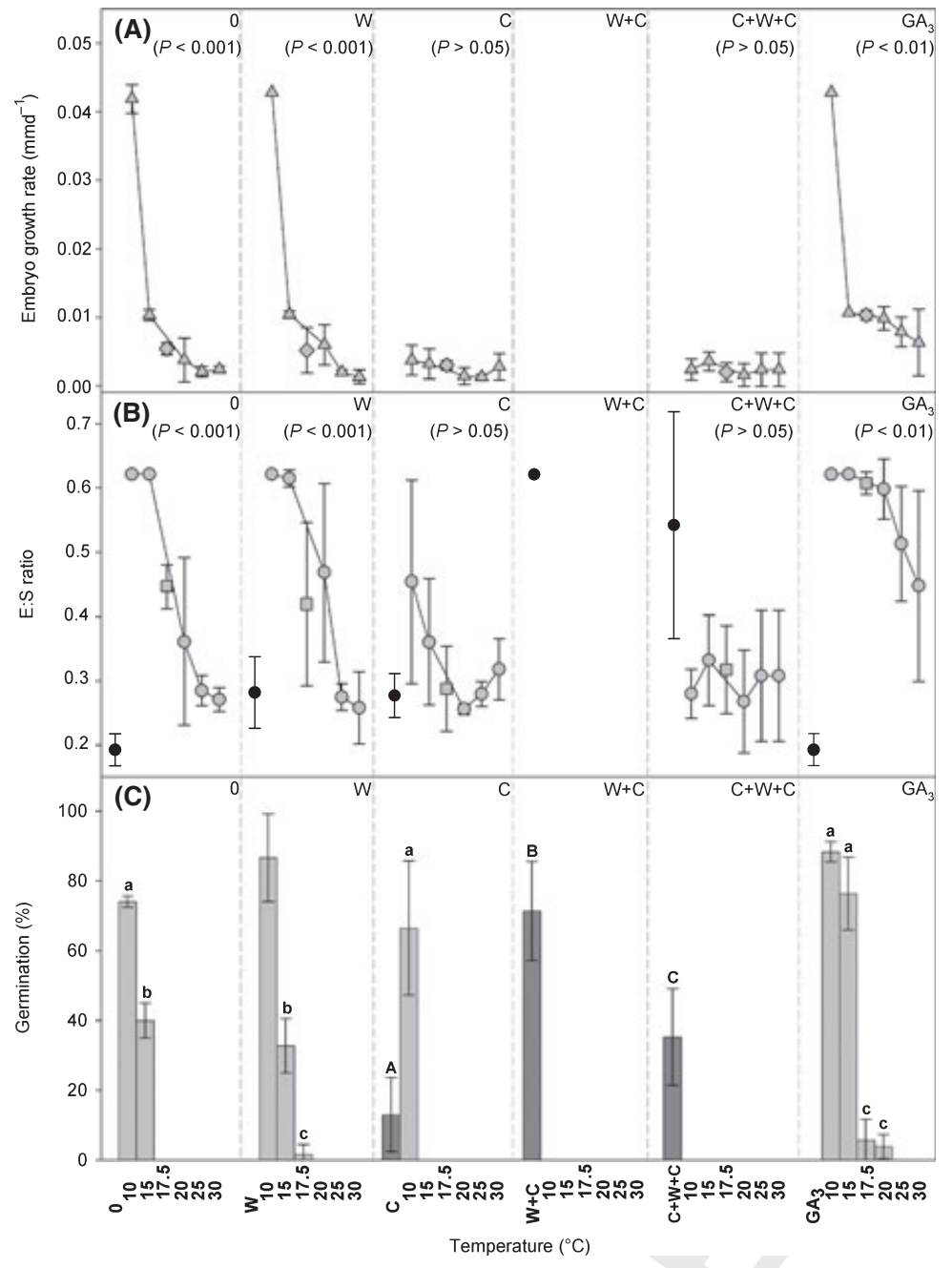

Fig. 3. Rate of embryo growth (A), final values of $E: S$ ratio (B), and cumulative germination percentages (C) achieved at the end of germination tests, after each pre-treatment $\left(0\right.$, control; $\mathrm{W}, 25^{\circ} \mathrm{C}$ for 3 months; $\mathrm{C}$, $5{ }^{\circ} \mathrm{C}$ for 3 months; $\mathrm{W}+\mathrm{C}, 25^{\circ} \mathrm{C}$ for 3 months and then $5{ }^{\circ} \mathrm{C}$ for another 3 months; $\mathrm{C}+\mathrm{W}+\mathrm{C}, 5^{\circ} \mathrm{C}$ for 3 months, $25^{\circ} \mathrm{C}$ for another 3 months and $5{ }^{\circ} \mathrm{C}$ for the last 3 months; see Table 2). E:S ratio measured at the start of germination tests (and therefore the end of pre-treatments for $\mathrm{W}, \mathrm{C}, \mathrm{W}+\mathrm{C}$ and $\mathrm{C}+\mathrm{W}+\mathrm{C}$ ), as well as seeds germinated during pre-treatments (see also Fig. 1) are reported here as a reference, with black circles (B) and dark grey bars (C). The results in the alternating temperature regime $\left(25 / 10^{\circ} \mathrm{C}\right)$ are here reported as $17.5^{\circ} \mathrm{C}$ and highlighted with a different symbol (diamonds and squares for embryo growth rate and $\mathrm{E}: \mathrm{S}$ ratio, respectively) compared to constant temperature values. Data are the mean of five seeds $( \pm S D)$ for embryo growth rate and E:S ratio, and of three replicates $( \pm$ SD) for germination data. A non-parametric Kruskal-Wallis test was carried out within each pre-treatment to test differences in values of either embryo growth rate or E:S ratio, and oneway ANOVA was used for germination data. In (C) bars with the same letter are not different at $P>0.05$ with post hoc Fisher's LSD (capital letters used for seeds germinated during pre-treatments). ature and their interaction had a significant effect on seed germination $(P<0.001)$. Intra-population variability was also detected among seedlots from Orgosolo. Seedlot OR08 had high germination percentages after $\mathrm{W}$ pre-treatment, both at $10{ }^{\circ} \mathrm{C}$ (ca. $85 \%$, see Fig. 3C) and $5{ }^{\circ} \mathrm{C} \mathrm{(ca.} 70 \%$, see Fig. 2). While no differences in germination were detected at $10{ }^{\circ} \mathrm{C}$ $(\mathrm{P}>0.05)$, germination of the two seedlots at $5{ }^{\circ} \mathrm{C}$ was statistically different $(\mathrm{P}<0.001)$.

A delay of about 2 months was detected between the onset of seed germination (radicle emergence) and epicotyl emergence in the three investigated populations. Only seeds that germinated at $10{ }^{\circ} \mathrm{C}$ were monitored for epicotyl emergence, due to the low germination percentages at $5{ }^{\circ} \mathrm{C}$ in all populations (Fig. 5). In BO09 ( $\mathrm{n}=9$ ), $67 \%, 89 \%$ and $33 \%$ of seeds that germinated produced elongated epicotyls at 10, 15 and $20{ }^{\circ} \mathrm{C}$, respectively, without any treatment (Fig. 5A). After 2 months of cold stratification (Fig. 5B), epicotyls emerged from all seeds that germinated $(100 \%)$ at 10 and $15^{\circ} \mathrm{C}$ and from $89 \%$ of those germinated at $20^{\circ} \mathrm{C}$. After $\mathrm{GA}_{3}$ treatment (Fig. 5C), only $67 \%, 56 \%$ and $22 \%$ of epicotyls emerged at 10,15 and $20{ }^{\circ} \mathrm{C}$, respectively, mainly due to high microbial growth and seedling mortality ( $c a .50 \%$, data not shown) at all tested temperatures (Fig. 5). In OR09 $(\mathrm{n}=15)$, the same pattern was detected (Fig. 5), with more epicotyls emerging at $10{ }^{\circ} \mathrm{C}(67 \%, 93 \%$ and $71 \%$ for control, cold stratification and $\mathrm{GA}_{3}$ treatment, respectively) and $15{ }^{\circ} \mathrm{C}(67 \%, 67 \%$ and $71 \%)$ than at $20^{\circ} \mathrm{C}(7 \%, 53 \%$ and $50 \%)$. Also in this case, high seedling mortality (ca. 26\%, data not shown) was detected for $\mathrm{GA}_{3}$ treatment at all temperatures. Considering the low germination even at $10^{\circ} \mathrm{C}$ for seeds from the TE09, a very low number of germinated seeds was sown at the different conditions for epicotyl emergence $(n=4)$ in this population. However, also in TE09, epicotyl emergence was higher at 10 and $15{ }^{\circ} \mathrm{C}$ than at $20^{\circ} \mathrm{C}$ (Fig. 5), except for the control (A), where no emergence occurred at $15{ }^{\circ} \mathrm{C}$ and high seedling mortality was detected after $\mathrm{GA}_{3}$ treatment (ca. $42 \%$, data not shown). No significant differences were detected among populations $(\mathrm{P}>0.05)$; however, epicotyl emergence was significantly affected by both applied treatment and temperature $(P<0.05)$, although their interaction was not significant $(\mathrm{P}>0.05$, two-way ANOvA).

The climate diagrams show a bi-seasonal Mediterranean trend for all three population sites, with a rainy and cool season from September to June and 3 months of dry and warm summer weather (Fig. 5). By synchronising the start of warm stratification with the month of dispersal (August), it was possible to predict that seeds would reach maximum germination in November, at the beginning of the winter season for all populations (Fig. 5). Without any treatment, maximum epicotyl emergence was achieved in April-May for 


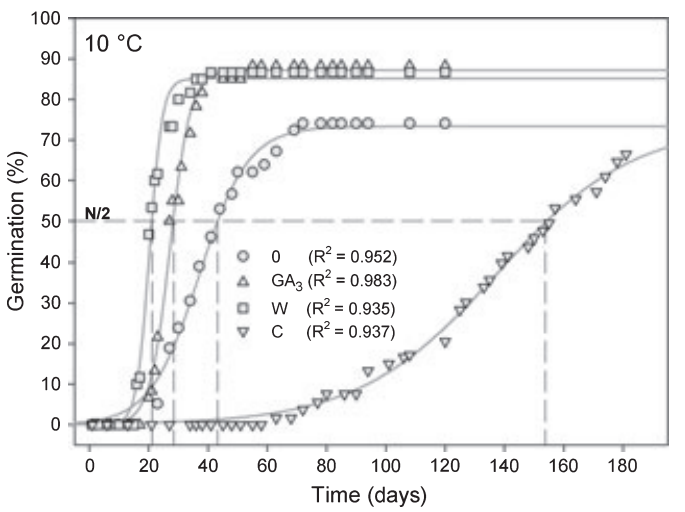

Fig. 4 Germination trends at $10^{\circ} \mathrm{C}$ after each pre-treatment (0, control; $\mathrm{W}, 25^{\circ} \mathrm{C}$ for 3 months and $\mathrm{C}, 5^{\circ} \mathrm{C}$ for 3 months; see Table 2). Points correspond to actual data and solid lines indicate the fitted lines from sigmoidal regressions $(P<0.0001$ for all lines). Data are mean of three replicates. For clarity, SD error bars are not shown, but were generally about $10 \%$. Dashed lines indicate $T_{50}$ values: times to achieve $50 \%(\mathrm{~N} / 2)$ maximum germination.

Bolotana and March for Orgosolo and Tempio populations. After 2 months of cold stratification, the maximum would be delayed to May at $20{ }^{\circ} \mathrm{C}$ for all populations, while at lower temperatures $\left(10\right.$ and $15{ }^{\circ} \mathrm{C}$ ) it would be reached 1 month earlier than the control (February-March) for Bolotana, and in March-April for Orgosolo and Tempio populations. After
$\mathrm{GA}_{3}$ treatment, maximum epicotyl emergence would be achieved before April at all temperatures for all populations (Fig. 5).

The applied treatments had a significant effect on mean time to epicotyl emergence (MTE; P $<0.001$ ), with lower mean values detected after both cold stratification and $\mathrm{GA}_{3}$ treatment $\left(74 \pm 28\right.$ days and $28 \pm 14$ days for $\mathrm{C}$ and $\mathrm{GA}_{3}$, respectively) than in the control ( $94 \pm 30$ days), even if only the latter was significantly different $(\mathrm{P}<0.05$; Fig. 6). Temperature and population had no effect on MTE $(\mathrm{P}>0.05)$.

\section{DISCUSSION}

Physical dormancy and water uptake

The similar increase in seed mass for both intact and scarified seed confirms that the seed coat of $R . m$. sandalioticum is water-permeable. Thus seeds of this taxon do not have physical dormancy (PY). Although several studies have shown a positive effect of scarification on germination of Ribes seeds (Fivaz 1931; Adam \& Wilson 1967; Pfister 1974; Rosner et al. 2003a,b), members of the Grossulariaceae do not have a water-impermeable palisade layer of cells in the seed coat (Baskin et al. 2000, 2006). Thus, promotion of germination following scarification is good evidence for the presence of physiological dormancy (PD) (Baskin \& Baskin 1998).

Although methylene blue failed to reach the endosperm and embryo, it was clear that embryos had undergone significant imbibition. Methylene blue staining has been used in

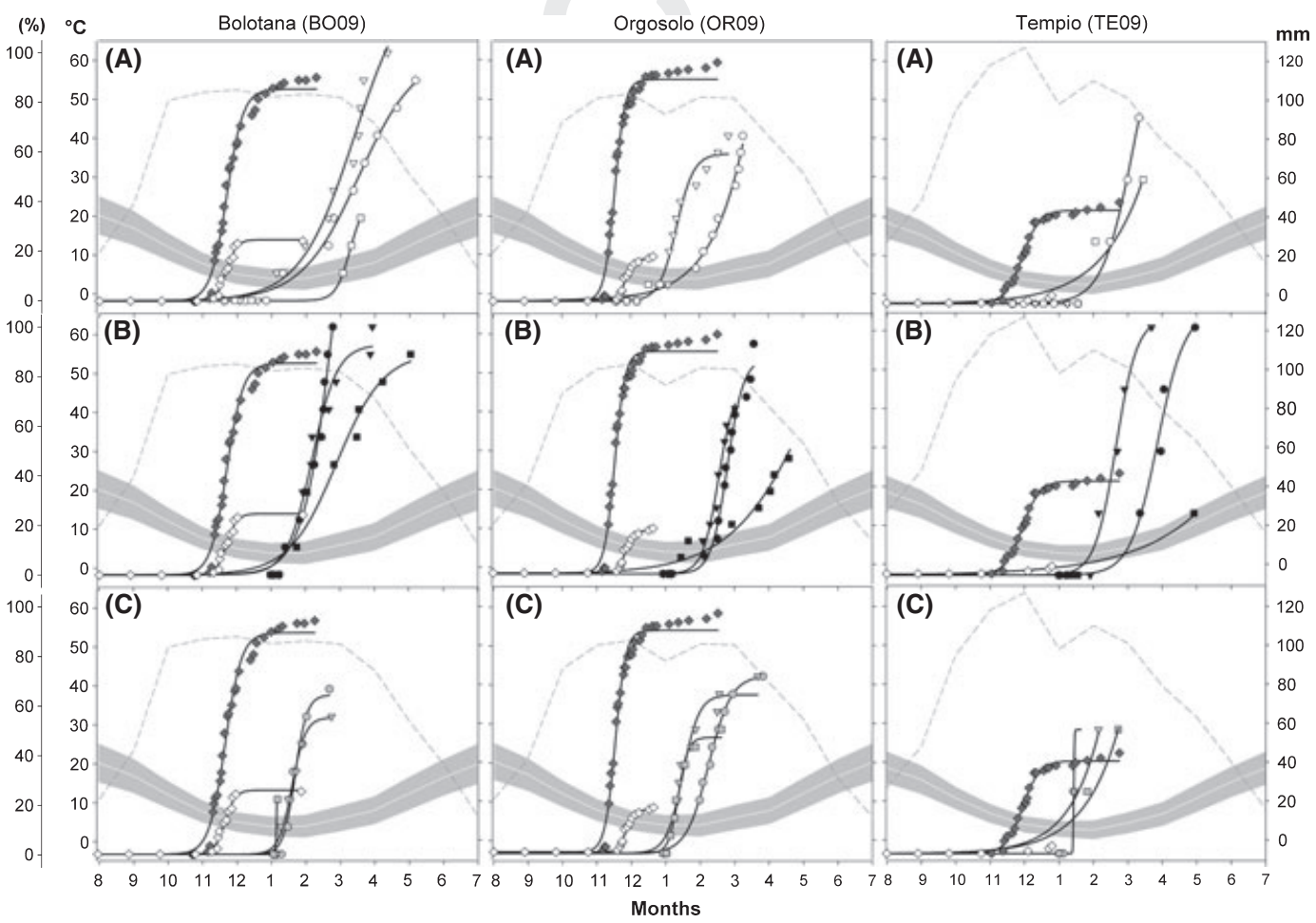

Fig. 5. Germination (root emergence) at $5^{\circ} \mathrm{C}$ (white diamonds) and $10{ }^{\circ} \mathrm{C}$ (dark diamonds) after $\mathrm{W}$ treatment $\left(25^{\circ} \mathrm{C}\right.$ for 90 days) and epicotyl emergence at $10{ }^{\circ} \mathrm{C}$ (circles), $15^{\circ} \mathrm{C}$ (triangles) and $20^{\circ} \mathrm{C}$ (squares) for each population, white symbols without any treatment (A); dark symbols after 2 months at

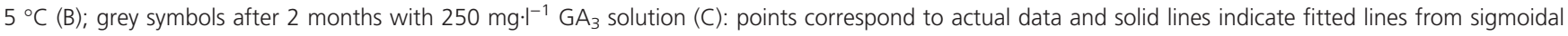
regressions. Annual trends of temperature (grey solid bands) and rainfall (grey medium dashed lines) are also reported for each population (data from WorldClim, http://www.worldclim.org); annual trends start from the month of natural dispersal (8: August). 


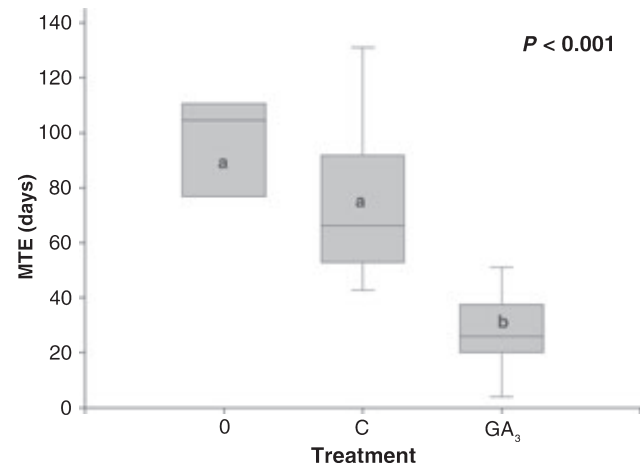

Fig. 6. Mean time of epicotyl emergence (MTE) for different treatments (0, control; C, 2 months at $5{ }^{\circ} \mathrm{C} ; \mathrm{GA}_{3}, 2$ months with $250 \mathrm{mg} \cdot \mathrm{l}^{-1} \mathrm{GA}_{3}$ solution), calculated as average values of all tested temperatures for all seedlots collected in 2009; P $<0.001$ in one-way ANova; data are mean of 252 seedlings; boxes with the same letter are not different at $P>0.05$ from post hoc Fisher's LSD test.

several studies to identify the pathway of water uptake into seeds (e.g. Tillman-Sutela \& Kauppi 1998; Orozco-Segovia et al. 2007). However, this staining method is an indirect approach, as permeability of the seed coat may be different from that for water (MW: $18.01 \mathrm{~g} \cdot \mathrm{mol}^{-1}$ ) and other, especially larger, molecules (e.g. methylene blue MW: $319.85 \mathrm{~g} \cdot \mathrm{mol}^{-1}$ ). In a study of seed coat imposed dormancy in Grevillea linearifolia (Cav.) Druce (Proteaceae), Briggs \& Morris (2008) found only small changes in permeability of high MW compounds (Lucifer yellow $\mathrm{CH}$ dilithium salt, MW: $457.25 \mathrm{~g} \cdot \mathrm{mol}^{-1}$ ) between untreated and treated (heat shock and smoke) seeds, although the treatments increased germination. While potassium iodide dye (MW: $419.81 \mathrm{~g} \cdot \mathrm{mol}^{-1}$ ) was the most effective marker for visualisation of water uptake into the starchy endosperm of wheat (Triticum aestivum L.) grains, methylene blue and Congo red (MW: $696.68 \mathrm{~g} \cdot \mathrm{mol}^{-1}$ ) failed to infiltrate beyond the outer embryo tissue (Rathjen et al. 2009).

We identified the pathway of penetration for methylene blue solution into seed of $R$. m. sandalioticum. After cells of the gelatinous sarcotesta were imbibed, dye entered the seed through the raphe vascular bundle, reaching the chalazal region, where a tanniniferous chalazal plug (hypostase) prevented the solution from entering the endosperm. Despite the clear staining result, it is possible that water, being a much smaller molecule, reached the endosperm and embryo directly by penetrating the seed coat layers. However, it seems most likely that the bulk of water taken up by the seed followed the same pathway as the dye. Other methods, such as magnetic resonance micro-imaging (see Rathjen et al. 2009), will be needed to confirm the exact pathway(s) of water during imbibition of seeds of $R$. m. sandalioticum.

\section{Morphophysiological dormancy}

The embryo in seeds of R. m. sandalioticum is small at dispersal and must grow before radicle emergence. Therefore, following the dormancy classification system (Baskin \& Baskin 1998, 2004), these seeds are morphologically dormant (MD). Generally, if embryos have only MD, growth is completed in a relatively short period, and seeds germinate in
30 days or less (Baskin \& Baskin 2004). R. m. sandalioticum seeds germinated at low temperatures $\left(\leq 15^{\circ} \mathrm{C}\right)$ without any treatment; however, more than 60 days were required for reach maximum germination. After warm stratification and $\mathrm{GA}_{3}$ treatment, seeds germinated (radicles emerged) in 30 days, due to increased embryo growth and seed germination rates. Pritchard et al. (1993) found similar germination behaviour for a geophyte from temperate deciduous woodland (Arum maculatum L., Araceae). These authors demonstrated that dispersed seeds of this species were receptive to a warm temperature phase prior to germination in the cold, leading to increased germination. $\mathrm{GA}_{3}$ treatment also widened the temperature range for germination in $R . m$. sandalioticum seeds. Thus, seeds of this species also have a physiological component to dormancy (PD), and are morphophysiologically dormant (MPD). This is the first fully documented report of this class of seed dormancy in Grossulariaceae.

MPD is divided into nine levels: non-deep simple, intermediate simple, deep simple, deep simple epicotyl, non-deep simple epicotyl, deep simple double, non-deep complex, intermediate complex and deep complex (Baskin \& Baskin 1998, 2004; Baskin et al. 2008). In addition, Jayasuriya et al. (2010) reported a new kind of epicotyl PD in a tropical Fabaceae species, where the delay in plumule emergence is not correlated to an underdeveloped embryo. Epicotyl MPD is found in Piperales, Liliales, Ranunculales, Saxifragales, Dipsacales and Boraginaceae (unplaced in Euasterids I), mainly in herbaceous species (Baskin \& Baskin 1998; Baskin et al. 2008, 2009).

In the simple kinds of MPD, embryos grow at relatively high temperature $\left(\geq 10^{\circ} \mathrm{C}\right)$, while in complex kinds of MPD, embryos grow during cold stratification (Baskin et al. 2008). Interestingly, not only did pre-treatments starting with a cold stratification ( $\mathrm{C}$ and $\mathrm{C}+\mathrm{W}+\mathrm{C}$ ) fail to break $\mathrm{PD}$ in R. m. sandalioticum seeds but they imposed secondary dormancy, with delayed embryo growth and seed germination even at low temperatures. Thus, these seeds have a simple level of MPD. In addition, the delay detected between onset of seed germination (root emergence) and epicotyl emergence in this species can be described as a kind of simple epicotyl MPD.

Roots and shoots can have different levels of PD (Baskin \& Baskin 1983, 1986); therefore, to describe dormancy in seeds with simple epicotyl MPD, the level of PD (deep, intermediate and non-deep; Baskin \& Baskin 2004) in both the root and shoot must be described (Baskin et al. 2009). Warm stratification and $\mathrm{GA}_{3}$ treatment enhanced embryo growth and subsequent seed germination at low temperatures; therefore, R. m. sandalioticum roots have non-deep PD. GA treatment also positively affected epicotyl emergence, while the effect of cold stratification, even if positive, was not statistically significant. Therefore, epicotyls of $R$. m. sandalioticum have non-deep PD, and seeds have non-deep simple (root) - non-deep simple (epicotyl) MPD. Baskin et al. (2009) recently described this level of epicotyl MPD for another woody member of the Saxifragales (Daphniphyllum glaucescens Blume subsp. oldhamii (Hemsl.) var. oldhamii (Hemsl.), Daphniphyllaceae), and it was first described by Baskin et al. (2008) in another woody species, Viburnum odoratissimum Ker Gawl. (Caprifoliaceae). These authors found that seeds of the latter species did not match the 'classical' 
deep simple epicotyl MPD for which cold stratification of seeds with emerged radicles is required for epicotyl emergence. In seeds of $V$. odoratissimum with an emerged radicle, there was a delay of one to several weeks for epicotyl emergence, depending on incubation temperature. However, unlike other species of Viburnum (such as V. acerifolium L., $V$. dentatum L. and $V$. dilatatum Thunb.), no cold stratification was required for epicotyl emergence (Baskin et al. 2008).

\section{Ecological correlates of seed germination and seedling establishment}

Berries of R. m. sandalioticum ripen in summer and dispersal takes place in August, mainly by endozoochory (birds and/or mammals), although many fruits simply drop to the ground (unassisted dispersal). Following dispersal, in late summer the seeds are exposed to warm temperatures (mean air temperature $>20^{\circ} \mathrm{C}$ ), and from September onwards they also experience increased availability of water through higher rainfall. In intact seeds, water presumably first causes the matrix of the sarcotesta to swell so as to produce temporary water storage around the seed in the form of a gelatinous pulp, and then water penetrates through both the inner layers of the seed coat and the hilum, from where it travels through the raphe into the chalaza before entering the endosperm and finally reaching the embryo.

Once imbibed, embryos may start to grow inside the seeds. However, it is only when mean temperatures drop below $10{ }^{\circ} \mathrm{C}$ in November-December and following annual maximum precipitation that embryo growth reaches the critical E:S ratio (mean embryo length of $c a .1 .80 \mathrm{~mm}$ ), thereby allowing seeds to germinate. Germinated seeds go through the winter with an emerged radicle, and epicotyls emerge only after 2 months (April), when mean air temperatures again reach $10-15{ }^{\circ} \mathrm{C}$. Seedling establishment is completed before the end of the wet season (June). Seedling growth can take place for 2 months, until the start of summer, so that the seedlings enter the dry summer period (June-August) with well-developed root and shoot systems.

Secondary dormancy of non-germinated seeds imposed by cold stratification prevents radicle emergence in late spring and exposure of recently emerged seedlings to the dry summer conditions that would most likely kill them.

\section{Intraspecific variability}

While seeds of the Bolotana and Orgosolo populations had a similar response to treatments and germination conditions, those from the highest population (Tempio) had low seed germination at both 5 and $10{ }^{\circ} \mathrm{C}$. Variability in seed dormancy between and within seedlots in Ribes has been observed by several authors (Pfister 1974; Young \& Young 1992; Rosner et al. 2003a,b). In particular, Rosner et al. (2003a,b) detected a latitudinal and altitudinal gradient in the effect of cold stratification on seeds of Ribes cereum Dougl from New Mexico. However, it is unlikely that the difference detected among $R$. m. sandalioticum populations was due to differences in dormancy breaking or germination requirements. Seeds were all collected in the same year (2009) and the three climatic diagrams highlight the same trends in temperature and rainfall. The low germination detected for the Tempio population may instead be due to poor quality of the seedlot, as suggested by the lower seed mass of these seeds compared to the other seedlots (see Table 1).

Variability in the level of seed dormancy was also detected between seeds collected in different years from the same population (Orgosolo). Seeds collected in 2008 were also able to germinate at $5{ }^{\circ} \mathrm{C}$, with high percentage germination $(>70 \%)$ after warm stratification; while seeds collected in 2009 failed to achieve more than $30 \%$ germination after the same pretreatment. A widening of the temperature range for germination is effect of after-ripening, i.e. a period of usually several months of dry storage at room temperature of freshly harvested, mature seeds (Finch-Savage \& Leubner-Metzger 2006). Mira et al. (2011) found that Silene diclinis (Lag.) M. Laínz seeds need more than 964 days of dry storage at $5{ }^{\circ} \mathrm{C}$ to lose dormancy. Therefore, it is likely that the higher germination at $5{ }^{\circ} \mathrm{C}$ in $R$. m. sandalioticum seeds after 9 months (ca. 270 days) of dry storage at $5{ }^{\circ} \mathrm{C}$ may be due to incipient after-ripening during storage. The same process could also explain the high germination without any pre-treatment reported in Liu et al. (2008) for seed bank collections of several Ribes species. Therefore, regardless of age, it is likely that the seeds had the same level of MPD at the time of dispersal.

\section{CONCLUSIONS}

Embryo growth and seed germination of R. $m$. sandalioticum were positively affected by both warm stratification followed by cold temperatures and by $\mathrm{GA}_{3}$ treatment. Embryos were small at dispersal and needed to increase length three-fold to reach the critical embryo:seed ratio required for germination. $\mathrm{GA}_{3}$ also had a positive effect on epicotyl emergence, which was delayed with respect to root emergence. Based on these results, the presence of a non-deep simple (root)-non-deep simple (epicotyl) MPD is reported for seeds of this species. A more extensive study should be carried out in order to investigate MPD in the genus Ribes, as also suggested by Baskin \& Baskin (2007), through a comparison of dormancy-breaking treatments and germination requirements in several species of this genus. Seeds of the investigated species showed high specialisation with respect to water uptake, seed germination and seedling establishment, which were synchronised with the Mediterranean seasonality in all the investigated populations. Moreover, the sensitivity of this species to low temperatures for seed germination highlighted an increasing threat from global warming, which could reduce the level of natural emergence in the field. The reported data may help establish ex situ conservation programmes for this rare species using seed banking and multiplication in nurseries and to initiate seed ecology studies on the very threatened congener R. sardoum.

\section{ACKNOWLEDGEMENTS}

The authors thank R. Buttau, A. Congiu, R. Cossu, G. Fenu and M. Giuliano for help with fieldwork, and K. Liu (SCD, Kew Gardens) for WorldClim data. The CCB is supported by the Provincia di Cagliari - Assessorato Tutela Ambiente, the Royal Botanic Gardens, Kew, receives grant-in-aid from Defra, UK. This research was funded by the Ente Foreste della Sardegna. 


\section{REFERENCES}

Adam J., Wilson D. (1967) Factors effecting the germination of blackcurrant seed. Annual Report of the Long Ashton Research

10 Station for 1966: 96-103.

Arrigoni P.V. (1968) Ribes multiflorum Kit. ssp. sandalioticum nuova sottospecie di Sardegna. Webbia, 23, 305-313.

Arrigoni P.V. (1981) Le piante endemiche della Sardegna: 86: Ribes sandalioticum (Arrigoni) Arrigoni stat. nov. Bollettino Società Sarda Scienze Naturali, 20, 244-248.

Baskin J.M., Baskin C.C. (1983) Germination ecophysiology of eastern decidous forest herbs: Hydrophyllum macrophyllum. American Midland Naturalist, 109, 63-71.

Baskin J.M., Baskin C.C. (1986) Germination ecophysiology of eastern decidous forest herbs: Asarum canadense. American Midland Naturalist, 116, 132-139.

Baskin C.C., Baskin J.M. (1998) Seeds - ecology, biogeography and evolution of dormancy and germination. Academic Press, San Diego.

Baskin C.C., Baskin J.M. (2003) When breaking seed dormancy is

11 a problem. Native Plants Journal, 4, 17-21.

Baskin J.M., Baskin C.C. (2004) A classification system for seed dormancy. Seed Science Research, 14, 1-16.

Baskin C.C., Baskin J.M. (2007) A revision of Martin's seed classification system, with particular reference to his dwarf-seed type. Seed Science Research, 17, 11-20.

Baskin J.M., Baskin C.C., Li X. (2000) Taxonomy, anatomy and evolution of physical dormancy in seeds. Plant Species Biology, 15, 139-152.

Baskin J.M., Baskin C.C., Dixon K.W. (2006) Physical dormancy in the endemic Australian genus Stylobasium, a first report for the family Suraniaceae. Seed Science Research, 16, 229-232.

Baskin C.C., Chien C.T., Chen S.Y., Baskin J.M. (2008) Germination of Viburnum odoratissimum seeds: a new level of morphophysiological dormancy. Seed Science Research, 18, 179-184.

Baskin C.C., Chien C.T., Chen S.Y., Baskin J.M. (2009) Epicotyl morphophysiological dormancy in seeds of Daphniphyllum glaucescens, a woody member of the Saxifragales. International Journal of Plant Sciences, 170(2), 174-181.

Briggs C.L., Morris E.C. (2008) Seed-coat dormancy in Grevillea linearifolia: little change in permeability to an apoplastic tracer after treatment with smoke and heat. Annals of Botany, 101(5), 623-632.

Carmignani L., Oggiano G., Barca S., Conti P., Eltrudis A., Funedda A., Pasci S. (2001) Note illustrative della Carta Geologica della Sardegna in scala 1:200.000 - Memorie descrittive della Carta Geologica d'Italia. Servizio Geologico d'Italia, Roma.

Corner E.J.H. (1976) The seeds of dicotyledons. Cambridge University Press, Cambridge.

Daws M.I., Burslem D.F.R.P., Crabtree L.M., Kirkman P., Mullins C.E., Dalling J.W. (2002) Differences in seed germination responses may promote coexistence of four sympatric Piper species. Functional Ecology, 16, 258-267.

Donohue K. (2005) Seeds and seasons: interpreting germination timing in the field. Seed Science Research, 15, 175-187.

Ellis R.H., Hong T.D., Roberts E.H. (1985) Handbook of seed technology for genebanks. Volume II. Compendium of specific germination information and test recommendations. IBPGR, Rome.
Fenu G., Mattana E., Congiu A., Bacchetta G. (2010) The endemic vascular flora of Supramontes (Sardinia), a priority plant conservation area. Candollea, 65(2), 347-358.

Finch-Savage W.E., Leubner-Metzger G.L. (2006) Seed dormancy and the control of germination. New Phytologist, 171, 501-523.

Fivaz A.E. (1931) Longevity and germination of seeds of Ribes, particularly $R$. rotundifolium, under laboratory and natural conditions. USDA Technical Bulletin No. 261.

Forbis T.A., Floyd S.K., de Querioz A. (2002) The evolution of embryo size in angiosperms and other seed plants: implications for the evolution of seed dormancy. Evolution, 56, 2112-2125.

Giménez-Benavides L., Escudero A., Pérez-García F. (2005) Seed germination of high mountain Mediterranean species: altitudinal, interpopulational and interannual variability. Ecological Research, 20, 433-444.

Goodwin J.R., Hummer K.E. (1993) Seed germination of Ribes hybrids. Fruit Varieties Journal, 47(4), 229-233.

Hidayati S.N., Baskin J.M., Baskin C.C. (2001) Dormancy-breaking and germination requirements for seeds of Symphoticarpos orbiculatus (Caprifoliaceae). American Journal of Botany, 88(8), 1444-1451.

Hijmans R.J., Cameron S.E., Parra J.L., Jones P.G., Jarvis A. (2005) Very high resolution interpolated climate surfaces for global land areas. International Journal of Climatology, 25, 1965-1978.

Hoyle G.L., Daws M.I., Steadman K.J., Adkins S.W. (2008) Mimicking a semi-arid tropical environment achieves dormancy alleviation for seeds of Australian native Goodeniaceae and Asteraceae. Annals of Botany, 101, 701-708.

Jayasuriya K.M.G.G., Wijetunga A.S.T.B., Baskin J.M., Baskin C.C. (2010) Recalcitrancy and a new kind of epicotyl dormancy in seeds of the understory tropical rainforest tree Humboldtia laurifolia (Fabaceae, Cesalpinoideae). American Journal of Botany, 97(1), 15-26.

Karlsson L.M., Milberg P. (2008) Variation within species and inter-species comparison of seed dormancy and germination of four annual Lamium species. Flora, 203, 409-420.

Karlsson L.M., Tamado T., Milberg P. (2008) Inter-species comparison of seed dormancy and germination of six annual Asteraceae weeds in an ecological context. Seed Science Research, 18, 35-45.

Liu K., Eastwood R.J., Flynn S., Turner R.M., Stuppy W.H. (2008) Seed information database (release 7.1, May 2008). Available from http://www.kew.org/data/sid (accessed 20 November 2008).

Mabberley D.J. (2008) Mabberley's plant-book, 3rd edition. Cambridge University Press, Cambridge.

Martin A.C. (1946) The comparative internal morphology of seeds. American Midland Naturalist, 36, 513-660.

Médail F., Diadema K. (2009) Glacial refugia influence plant diversity patterns in the Mediterranean Basin. Journal of Biogeography, 36(7), 1333-1345.

Milberg P., Andersson L. (1998) Does cold stratification level out differences in seed germinability between populations? Plant Ecology, 134, 225-234.

Mira S., González-Benito M.E., Ibars M.I., Estrelles E. (2011) Dormancy release and seed ageing in the endangered species Silene diclinis. Biodiversity and Conservation, 20(2) Sp. Iss. SI, 345358. 
Mondoni A., Probert R., Rossi G., Hay F., Bonomi C. (2008) Habitat-correlated seed germination behaviour in populations of wood anemone (Anemone nemorosa L.) from northern Italy. Seed Science Research, 18, 213-222.

Orozco-Segovia A., Márquez-Guzmán J., Sánchez-Coronado M.E., Gamboa de Buen A., Baskin J.M., Baskin C.C. (2007) Seed anatomy and water uptake in relation to seed dormancy in Opuntia tomentosa (Cactaceae, Opuntioideae). Annals of Botany, 99(4), 581-592.

Pfister R.D. (1974) Ribes L. Currant, Gooseberry. In: Schopmeyer C.S. (Ed.), Seeds of woody plants of the United States. USDA Forest Service, Washington (DC). Agriculture Handbook No 450,

13 pp 720-727.

Pritchard H.W., Wood J.A., Manger K.R. (1993) Influence of temperature on seed germination and nutritional requirements for embryo growth in Arum maculatum L. New Phytologist, 123, 801-809.

R Development Core Team (2010) R: A language and environment for statistical computing. R Foundation for Statistical Computing,

14 Vienna, Austria. Available from http://www.R-project.org/ Rathjen J.R., Strounina E.V., Mares D.J. (2009) Water movement into dormant and non-dormant wheat (Triticum aestivum L.) grains. Journal of Experimental Botany, 60(6), 1619-1631.

Rosner L.S., Harrington J.T., Dreesen D.R., Murray L. (2003a) Hydrogen peroxide seed scarification of New Mexico collections of Ribes cereum. Seed Science and Technology, 31, 71-81.
Rosner L.S., Harrington J.T., Dreesen D.R., Murray L. (2003b) Sulfuric acid scarification of wax currant seeds from New Mexico. Native Plants Journal, 4(1), 65-71.

Tillman-Sutela E., Kauppi A. (1998) Structures restricting passage of water in the mature seeds of yellow-cedar (Chamaecyparis nootkatensis). Canadian Journal of Botany, 76, 1458-1466.

Tzedakis P.C., Lawson I.T., Frogley M.R., Hewitt G.M., Preece R.C. (2002) Buffered tree population changes in a quaternary refugium: evolutionary implications. Science, 297, 2044.

Valsecchi F. (1977) Biologia, posizione sistematica ed ecologia di Ribes sardoum Martelli e Ribes multiflorum Kit. ssp. sandalioticum Arrigoni. Webbia, 31(2), 279-294.

Vandelook F., Bolle N., Van Assche J.A. (2007) Multiple environmental signals required for embryo growth and germination of seeds of Selinum carvifolia (L.) L. and Angelica sylvestris L. (Apiaceae). Seed Science Research, 17, 283-291.

Vandelook F., Van de Moer D., Van Assche J.A. (2008) Environmental signals for seed germination reflect habitat adaptations in four temperate Caryophyllaceae. Functional Ecology, 22, 470478.

Young J.A., Young C.G. (1992) Seeds of woody plants in North America. Dioscorides Press, Portland, OR. 


\section{Author Query Form}

\section{Journal: $\quad$ PLB}

Article: $\quad 476$

Dear Author,

During the copy-editing of your paper, the following queries arose. Please respond to these by marking up your proofs with the necessary changes/additions. Please write your answers on the query sheet if there is insufficient space on the page proofs. Please write clearly and follow the conventions shown on the attached corrections sheet. If returning the proof by fax do not write too close to the paper's edge. Please remember that illegible mark-ups may delay publication.

Many thanks for your assistance.

\begin{tabular}{|c|c|c|}
\hline Query reference & Query & Remarks \\
\hline 1 & $\begin{array}{l}\text { Author: Starting in } 2011 \text {, research articles will be subject to a page charge at a } \\
\text { rate of GBP } 100 \text { per page above the } 8 \text {-page limit (the first } 8 \text { pages are free of } \\
\text { charge). Your article exceeds the page limit. Please either make the necessary } \\
\text { changes for the article to fit into } 8 \text { pages or go to the journal website, down- } \\
\text { load the Page Charges Form, fill it in and send it to the production editor at } \\
\text { Wiley-Blackwell (please, click on the following link to download the form: } \\
\text { http://www.blackwellpublishing.com/pdf/PLB_Page_Charge_Form.pdf). }\end{array}$ & \\
\hline 2 & $\begin{array}{l}\text { AUTHOR: As per journal style abbreviation are not allowed in the title hence } \\
\text { GA }_{3} \text { has been changed to Gibberellic acid, Please check and confirm it is ok. }\end{array}$ & \\
\hline 3 & $\begin{array}{l}\text { AUTHOR: Please check all website address and confirm that it is correct. } \\
\text { (Please note that it is the responsibility of the author(s) to ensure that all URLs } \\
\text { given in this article are correct and useable.) }\end{array}$ & \\
\hline 4 & $\begin{array}{l}\text { AUTHOR: Please give manufacturer information for Leica CM3050S: company } \\
\text { name, town, state (if USA), and country. }\end{array}$ & \\
\hline 5 & AUTHOR: Please provide city name for Carl Zeiss MicroImaging. & \\
\hline 6 & $\begin{array}{l}\text { AUTHOR: In the sentence 'incubated in the light }(12 \mathrm{~h} \text { light } / 12 \mathrm{~h} \text { dark' - Miss- } \\
\text { ing of closing parenthesis, Please check. }\end{array}$ & \\
\hline 7 & $\begin{array}{l}\text { AUTHOR: Please give manufacturer information for Epson GT-15000: company } \\
\text { name, town, state (if USA), and country. }\end{array}$ & \\
\hline 8 & $\begin{array}{l}\text { AUTHOR: Please give address information for National Institutes of Health: } \\
\text { town and state (if applicable). }\end{array}$ & \\
\hline 9 & AUTHOR: Fig. 2B has been changed to Fig. 2. Please check. & \\
\hline 10 & $\begin{array}{l}\text { AUTHOR: Please provide missing details if any for reference Adam and Wilson } \\
(1967) \text {. }\end{array}$ & \\
\hline 11 & $\begin{array}{l}\text { AUTHOR: Please check the journal name for 'Native Plants Journal' for cor- } \\
\text { rectness. }\end{array}$ & \\
\hline 12 & $\begin{array}{l}\text { AUTHOR: Karlsson and Milberg }(2008) \text { has not been cited in the text. Please } \\
\text { indicate where it should be cited; or delete from the Reference List. }\end{array}$ & \\
\hline
\end{tabular}




\begin{tabular}{|l|l|l|}
\hline 13 & AUTHOR: Please check the reference Pfister (1974). & \\
\hline 14 & $\begin{array}{l}\text { AUTHOR: Please provide Accessed date, month and year for reference R Devel- } \\
\text { opment Core Team (2010). }\end{array}$ & \\
\hline
\end{tabular}




\section{Please correct and return this set}

Please use the proof correction marks shown below for all alterations and corrections. If you wish to return your proof by fax you should ensure that all amendments are written clearly in dark ink and are made well within the page margins.

\begin{tabular}{|c|c|c|}
\hline Instruction to printer & Textual mark & Marginal mark \\
\hline Leave unchanged & ... under matter to remain & ( ) \\
\hline $\begin{array}{l}\text { Insert in text the matter } \\
\text { indicated in the margin }\end{array}$ & $h$ & $\begin{array}{l}\text { New matter followed by } \\
h \text { or } h \otimes\end{array}$ \\
\hline Delete & $\begin{array}{l}\text { I through single character, rule or underline } \\
\text { or }\end{array}$ & $\sigma$ or $\sigma(x)$ \\
\hline $\begin{array}{l}\text { Substitute character or } \\
\text { substitute part of one or } \\
\text { more word(s) }\end{array}$ & I through letter or & $\begin{array}{l}\text { new character / or } \\
\text { new characters / }\end{array}$ \\
\hline Change to italics & — under matter to be changed & $\leftarrow$ \\
\hline Change to capitals & $\equiv$ under matter to be changed & $\equiv$ \\
\hline Change to small capitals & $=$ under matter to be changed & $=$ \\
\hline Change to bold type & $\sim$ under matter to be changed & $\sim$ \\
\hline Change to bold italic & $\bar{\sim}$ under matter to be changed & $\underline{s i n}$ \\
\hline Change to lower case & Encircle matter to be changed & $\Rightarrow$ \\
\hline Change italic to upright type & (As above) & \\
\hline Change bold to non-bold type & (As above) & \\
\hline Insert 'superior' character & $\begin{array}{l}/ \text { through character or } \\
K \text { where required }\end{array}$ & $\begin{array}{l}y^{\prime} \text { or } y \\
\text { under character } \\
\text { e.g. } y^{2} \text { or } y^{2}\end{array}$ \\
\hline Insert 'inferior' character & (As above) & $\begin{array}{l}\lambda \\
\text { over character } \\
\text { e.g. } \hat{\Sigma}\end{array}$ \\
\hline Insert full stop & (As above) & $\odot$ \\
\hline Insert comma & (As above) & , \\
\hline Insert single quotation marks & (As above) & $\begin{array}{l}\dot{y} \text { or } \dot{x} \text { and/or } \\
\dot{y} \text { or } \dot{y}\end{array}$ \\
\hline Insert double quotation marks & (As above) & $\begin{array}{l}\ddot{y} \text { or } \ddot{y} \text { and/or } \\
\ddot{y} \text { or } \ddot{y}\end{array}$ \\
\hline Insert hyphen & (As above) & 1 \\
\hline Start new paragraph & 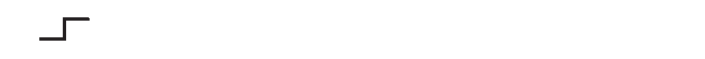 & 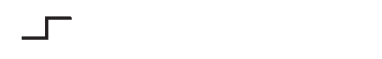 \\
\hline No new paragraph & $\infty$ & $\omega$ \\
\hline Transpose & $\sqcup$ & $\sqcup$ \\
\hline Close up & linking $\bigcirc$ characters & \\
\hline $\begin{array}{l}\text { Insert or substitute space } \\
\text { between characters or words }\end{array}$ & $\begin{array}{l}\text { I through character or } \\
\Lambda \text { where required }\end{array}$ & \\
\hline $\begin{array}{l}\text { Reduce space between } \\
\text { characters or words }\end{array}$ & $\begin{array}{l}\text { between characters or } \\
\text { words affected }\end{array}$ & $\uparrow$ \\
\hline
\end{tabular}

